\title{
Pseudozyma aphidis Induces Salicylic-Acid-Independent Resistance to Clavibacter michiganensis in Tomato Plants
}

Omer Barda, Or Shalev, Shanee Alster, Kobi Buxdorf, Aviva Gafni, and Maggie Levy, Department of Plant Pathology and Microbiology, The Robert H. Smith Faculty of Agriculture, Food and Environment, The Hebrew University of Jerusalem, Rehovot, Israel

\begin{abstract}
Barda, O., Shalev, O., Alster, S., Buxdorf, K., Gafni, A., and Levy, M. 2015. Pseudozyma aphidis induces salicylic-acid-independent resistance to Clavibacter michiganensis in tomato plants. Plant Dis. 99:621-626.

The ability of plant pathogens to rapidly develop resistance to commonly used pesticides challenges efforts to maximize crop production. Fungal biocontrol agents have become an important alternative to chemical fungicides as a result of environmental concerns regarding conventional pesticides, including resistance issues. The complex mode of action of biocontrol agents reduces the likelihood that pathogens will develop resistance to them. We recently isolated a unique, biologically active isolate of the epiphytic fungus Pseudozyma aphidis. We show that the extracellular metabolites secreted by our $P$. aphidis isolate can inhibit Xanthomonas campestris pv. vesicatoria, $X$. campestris pv. campestris, Pseudomonas syringae pv. tomato,

Erwinia amylovora, Clavibacter michiganensis, and Agrobacterium tumefaciens in vitro. Moreover, application of Pseudozyma aphidis spores on tomato plants in the greenhouse significantly reduced (by 60\%) the incidence of bacterial wilt and canker disease caused by $C$. michiganensis subsp. michiganensis on those plants as well as disease severity by $35 \%$. Furthermore, infected plants treated with $P$. aphidis were $25 \%$ taller than control infected plants. We found that $P$. aphidis activates PRIa-and other pathogenesis-related genes in tomato plants - and can trigger an induced-resistance response against C. michiganensis that proceeds in a salicylic-acid-independent manner, as shown using NahG-transgenic tomato plants.
\end{abstract}

Plant pathogens can rapidly develop resistance to pesticides, which can result in immense annual losses in yield. Fungal biocontrol agents have become an important alternative to the use of chemicals due to environmental concerns, including resistance issues. Repeated use of the same class of pesticides to control a pathogen can increase the proportion of less susceptible individuals in the pathogen population. In contrast, the ability of pathogens to develop resistance to biological control agents, which have complex modes of action (e.g., antibiosis, mycoparasitism, competition, or induced resistance in the host plant), is limited.

One important mode of action used by biocontrol agents to help protect plants from pathogens is induction of the plant's systemic resistance mechanisms. This induction process is often associated with upregulation of pathogenesis-related (PR) genes or accumulation of phytoalexins $(37,59,60,63)$. Studies of different fungal biocontrol agents have demonstrated the effectiveness of some of them against a variety of plant pathogens. For example, Trichoderma asperellum was shown to activate induced systemic resistance by modulating the expression of genes involved in the jasmonic acid/ethylene (JA/ET)signaling pathways. This mechanism provided effective biocontrol of a number of soilborne pathogens of cucumber (60). Penicillium simplicissimum was also found to activate an induced resistance response in Arabidopsis that involves JA/ET-signaling but also salicylic acid (SA)-signaling pathways (37). A similar effect was shown for the mycorrhizal fungus Piriformospora indica, which conferred resistance to powdery mildew through systemic resistance via JA signaling and NPR1 (63). On the other hand, transcriptional analysis of the interaction of $T$. hamatum with tomato plants failed to

O. Barda, O. Shalev, S. Alster, K. Buxdorf, and A. Gafni contributed equally to this work

Corresponding author: M. Levy; E-mail: maggie.Levy@ mail.huji.ac.il

*The $\boldsymbol{e}$-Xtra logo stands for "electronic extra" and indicates that two supplementary figures are published online.

Accepted for publication 11 October 2014.

http://dx.doi.org/10.1094/PDIS-04-14-0377-RE

(C) 2015 The American Phytopathological Society detect any induction of JA markers and, in the context of that interaction, only one systemic acquired resistance marker (PR5) was upregulated (2). These findings suggested that different mechanisms and pathways are used by different biocontrol agents to induce plant defense responses.

Biocontrol activity and natural barriers against certain plant pathogens can be provided by epiphytic yeasts colonizing different plant surfaces $(4,27,28,42,51,62,66)$. Diseases in the greenhouse and in storage have been shown to be controlled by specific yeasts and yeast-like fungal species and strains $(15,20,21,23,24,26,40,46,48,55)$. The genus Pseudozyma is a small group of yeast-like fungi that are related to the order Ustilaginales (11). Pseudozyma spp. are nonpathogenic to plants and animals and mostly epiphytic or saprophytic (4). Some species of Pseudozyma, such as Pseudozyma rugulosa and $P$. flocculosa, exhibit biological activity against different powdery mildews $(9,22,33-35,39)$. One possible mode of action in $P$. flocculos $a$ is secretion of an unusual fatty acid that exhibits antibiotic activity against several pathogens $(3,5,10,33)$. On the other hand, Avis et al. (5) showed that $P$. aphidis isolate CBS 517.83 does not secrete any antifungal fatty acids, nor does it inhibit Podosphaera xanthii (formerly Sphaerotheca fuliginea), the causal agent of powdery mildew. In our previous study $(12,13)$, we demonstrated that $P$. aphidis isolate L12, isolated from the surface of strawberry leaves, can serve as a biocontrol agent against Botrytis cinerea on Arabidopsis plants and that its biocontrol activity involves a dual mode of action: induced resistance and antibiosis. In that work, we concluded that the induced resistance observed in the Arabidopsis plants was JA, SA, and ET independent and that $P$. aphidis can bypass the SA/NPR1 pathway but not the JA pathway in order to activate the PR genes $P R I$ and $P D F 1.2(12,13)$.

In the current work, we demonstrate the potential of $P$. aphidis isolate L12 for use as a biocontrol agent against bacterial pathogens. We found that the secreted fraction of $P$. aphidis can inhibit a variety of plant bacterial pathogens in vitro and activate induced resistance against the bacterial pathogen Clavibacter michiganensis in tomato plants in an SA-independent manner.

\section{Materials and Methods}

P. aphidis culture. The P. aphidis isolate L12 was grown on potato dextrose agar (PDA; Difco) at $26^{\circ} \mathrm{C}$ and transferred to fresh medium monthly. Liquid cultures in potato dextrose broth (PDB; Difco) 
were inoculated with two $1-\mathrm{cm}^{2}$ blocks of PDA carrying mycelia or spores. The liquid culture was grown for 7 to 10 days on a rotary shaker set at $150 \mathrm{rpm}$ and kept at $26^{\circ} \mathrm{C}$. We obtained a concentration of $10^{8}$ conidia/ml after 10 days of growth in liquid culture. P. aphidis concentrations were determined by counting the cells in a hemocytometer. For long-term storage, P. aphidis spores were kept in 50\% glycerol at $-80^{\circ} \mathrm{C}$.

RNA isolation and quantitative real-time polymerase chain reaction analysis. Total RNA was isolated from tomato plants (Solanum lycopersicum cultivar 870) sprayed with water (control) and from treated plants 24 to $72 \mathrm{~h}$ after treatment with $P$. aphidis at $10^{8} \mathrm{spores} / \mathrm{ml}$ (suspended in water), with or without infection with $C$. michiganensis. This isolation was carried out using the Qiagen RNeasy kit (Invitrogen, San Diego, CA), according to the manufacturer's instructions, or the LogSpin method (72). DNase treatment was performed using Qiagen columns, according to the manufacturer's instructions (Invitrogen). Total RNA (1 $\mu \mathrm{g})$ was reverse-transcribed with an EZ-First-Strand cDNA synthesis kit (Biological Industries, Israel). Quantitative real-time polymerase chain reaction (PCR) was performed with SYBR master mix on a StepOne real-time PCR machine (Applied Biosystems, Foster City, CA). The thermal-cycling program was as follows: $95^{\circ} \mathrm{C}$ for $20 \mathrm{~s}$ and 40 cycles of $95^{\circ} \mathrm{C}$ for $3 \mathrm{~s}$ and $60^{\circ} \mathrm{C}$ for $30 \mathrm{~s}$. Relative fold-change in gene expression normalized to Tip41 expression in samples from treated versus water-sprayed (control) tomato leaves was calculated using the $2^{-\Delta \Delta C t}$ method (44). The primer sequences are listed in Table $1(7,25)$.

Isolation of $\boldsymbol{P}$. aphidis-secreted fraction for in vitro inhibition assays. Secreted metabolites were extracted from PDB culture filtrate using ethyl acetate and hexane. One and a half liters of PDB medium in a 3-liter Erlenmeyer flask was inoculated with two $1-\mathrm{cm}^{2}$ blocks of PDA carrying mycelia or spores of $P$. aphidis and grown for 21 days, kept at $26^{\circ} \mathrm{C}$ with constant agitation at $150 \mathrm{rpm}$. We then spun down the fungal cells (20 min at 10,000 rpm). The supernatant, consisting of culture filtrate, or PDB only was titrated to $\mathrm{pH} 2.0$ using $1 \mathrm{~N} \mathrm{HCl}$ and extracted with an equivalent volume of ethyl acetate using separating funnels. The ethyl-acetate fraction was collected, reextracted with hexane, and evaporated in a rotor evaporator (Buchi, Flawil, Switzerland) at $42^{\circ} \mathrm{C}(49)$. The dry fraction was reconstituted in methanol and used for in vitro experiments after the application of an equivalent of $2 \mathrm{mg}$ of the dry fraction to each Whatman paper disc (6 $\mathrm{mm}$ in diameter). The discs were placed in the center of PDA plates, which were inoculated with the different bacteria. Bacterial suspension $\left(4 \mathrm{ml}, 10^{9}\right.$ cells $\left./ \mathrm{ml}\right)$ were embedded in each $200 \mathrm{ml}$ of PDA (cooled to 45 to $50^{\circ} \mathrm{C}$ ) before pouring into petri dishes. The

Table 1. Primer sequences for pathogenesis-related genes used in this study

\begin{tabular}{|c|c|}
\hline Primer name & Sequence $3^{\prime}-5^{\prime}$ \\
\hline SITIP41 For & GCTGCGTTTCTGGCTTAGG \\
\hline SITIP41 Rev & ATGGAGTTTTTGAGTCTTCTGC \\
\hline SIPR1a For & GTCTGGCGCAACTCAGTCCGA \\
\hline SIPR1a Rev & TGCAAGAAATGAACCACCACCCA \\
\hline SlLoxD For & GCAACGAGGACTGGTGGCCC \\
\hline SlLoxD Rev & TTGCGCTGAAGCCAGCCAGA \\
\hline S1LePIN2 For & AATTATCCATCATGGCTGTTCAC \\
\hline SILePIN2 Rev & CCTTTTTGGATCAGATTCTCCTT \\
\hline SlLeChi3-For & TGCAGGAACATTCACTGGAG \\
\hline SlLeChi3-Rev & TAACGTTGTGGCATGATGGT \\
\hline SlLeChi9-For & GAAATTGCTGCTTTCCTTGC \\
\hline SlLeChi9-Rev & CTCCAATGGCTCTTCCACAT \\
\hline S1GlucA-For & GGTCTCAACCGCGACATATT \\
\hline SlGlucA-Rev & CACAAGGGCATCGAAAAGAT \\
\hline SlGlucB-For & TCTTGCCCCATTTCAAGTTC \\
\hline SlGlucB-Rev & TGCACGTGTATCCCTCAAAA \\
\hline SIPTI5 For & GAGAGTATGGCTAGGTACGTTCG \\
\hline SIPTI5 Rev & TAAGTAGTGCCTTAGCACCTCGC \\
\hline SIPR5 For & ATCGAGGCCAAACATGGGTCAT \\
\hline SIPR5 Rev & TTGGCATGAACCTCTACCAGCA \\
\hline
\end{tabular}

inhibition halo was measured after $48 \mathrm{~h}$ at the optimal temperature (depicted in parenthesis below) that was used for the pathogen's propagation.

Propagation of plants and pathogens. C. michiganensis subsp. michiganensis strain CMM44 $\left(30^{\circ} \mathrm{C}\right)$, Xanthomonas campestris pv. vesicatoria $\left(28^{\circ} \mathrm{C}\right), X$. campestris pv. campestris $\left(28^{\circ} \mathrm{C}\right)$, Agrobacterium tumefaciens $\left(32^{\circ} \mathrm{C}\right)$, Erwinia amylovora $\left(37^{\circ} \mathrm{C}\right)$, and Pseudomonas syringae pv. tomato $\left(27^{\circ} \mathrm{C}\right.$ ) (from our private collection) were grown on nutrient agar medium (NA; Difco) in a controlled incubator in complete darkness at the indicated temperatures.

Tomato plants (S. lycopersicum 870 ) were grown in soil in a greenhouse kept at a constant temperature of $25^{\circ} \mathrm{C}$ and $40 \%$ relative humidity under natural light conditions. Plants were kept in plastic containers which were filled with water for irrigation. The mutant tomato line $N a h G(29,47)$ and plants expressing its wild-type background (ecotype 'Money Maker') were also grown under the same conditions.

Inhibition of $C$. michiganensis infection of tomato plants. Twoweek-old greenhouse-grown tomato plants (S. lycopersicum cultivar 870) planted in pots $(15 \mathrm{~cm}$ in diameter) filled with soil mixture were sprayed with water (control) or with Pseudozyma aphidis $\left(10^{8}\right.$ spores $/ \mathrm{ml}$ suspended in water) until the spore suspension flowed off the plant. $P$. aphidis was allowed 2 to 3 days to become established on the plants. Then, the plants were inoculated with C. michiganensis subsp. michiganensis strain CMM44 that had been grown in nutrient broth at $30^{\circ} \mathrm{C}$ at a constant agitation of $150 \mathrm{rpm}$, by cutting the first leaf with scissors that had been dipped in the bacterial suspension (optical density at $600 \mathrm{~nm}$ of approximately 0.9). Plants from the different treatments were randomized in the greenhouse. Twenty-eight days after this inoculation, we rated the disease symptoms on these plants and on plants that had been treated only with water. Disease incidence was expressed as the percentage of plants that developed symptoms. Disease severity was assessed on a 0 -to- 5 scale as follows: $0=0 \%$ of leaves showing wilting; $0.5=$ slight marginal wilting, $10 \%$ of leaves with wilt; $1=20 \%$ of leaves with wilt; $1.5=30 \%$ of leaves with wilt; $2=$ $40 \%$ of leaves with wilt; $2.5=50 \%$ of leaves with wilt; $3=$ sectored wilting, $60 \%$ of leaves showing wilting associated with chlorosis; $3.5=70 \%$ of leaves with wilt; $4=80 \%$ of leaves with wilt; $4.5=$ pronounced leaf collapse, $90 \%$ of leaves showing wilting; and $5=100 \%$ of plant is wilted. A mean disease severity index was calculated for each treatment by adding up the scores of the 10 to 15 plants in the treatment and then expressing that sum as a percentage using the formula described by Raupach et al. (57): disease severity index $=\left[\sum\right.$ (rating number $\times$ number of plants in rating) $\times 100 \%] /($ total number of plants $\times$ highest rating). Biocontrol efficacy was calculated using the formula described here: efficacy $=[$ (disease rate in control - disease rate in treatment $) /$ disease rate in control] $\times 100$.

Determination of defense activation. The expression of PR genes was monitored in tomato plants 3 days after foliar application of $P$. aphidis $\left(10^{8}\right.$ spores $/ \mathrm{ml}$, suspended in water $)$ and compared with expression in plants treated with water (control) and with autoclaved dead $P$. aphidis. Gene expression in untreated and $P$. aphidis-treated plants was also monitored after inoculation with $C$. michiganensis.

Statistical analysis. Student's $t$ tests were performed only when data were normally distributed and the sample variances were equal. In all other cases, the Tukey-Kramer honestly significant difference test was used. Significance was accepted at $P<0.05$ (as noted in the text or table captions). All experiments described here are representative of at least two independent experiments with the same pattern of results.

\section{Results}

Extracts of $\boldsymbol{P}$. aphidis secretions inhibit a range of bacterial pathogens in vitro. The growth-inhibitory effect of $P$. aphidis extracts on several bacteria was evaluated by measuring the halos around filter paper saturated with extracts of $P$. aphidis isolate L12 
culture-filtrate metabolites. The inhibition of several bacterial pathogens' growth was observed (Fig. 1). A strong inhibitory effect of the extracts on $C$. michiganensis subsp. michiganensis (4.3- $\mathrm{cm}^{2}$ halo), which causes bacterial wilt and canker in tomato plants, as well as on $X$. campestris pv. vesicatoria $\left(1.7-\mathrm{cm}^{2}\right.$ halo), the causal agent of bacterial leaf spot on pepper and tomato, was observed. The extracts also had moderate inhibitory effects (0.7- to $1.2-\mathrm{cm}^{2}$ halo) on other bacterial pathogens: A. tumefaciens, E. amylovora, Pseudomonas syringae pv. tomato, and $X$. campestris pv. campestris (Fig. 1). No inhibitory effect was found on any of the pathogens using extracts from PDB only as control (data not shown).

$P$. aphidis reduces $C$. michiganensis infection in tomato. Application of suspensions of Pseudozyma aphidis spores $\left(10^{8}\right.$ spores $\left./ \mathrm{ml}\right)$ to tomato plants in the greenhouse 3 days prior to inoculation with C. michiganensis provided $60 \%$ control of bacterial wilt and canker disease 38 days after inoculation (Fig. 2). At this time point, we observed $100 \%$ mortality of the untreated plants whereas only $40 \%$ of the plants that had been treated with P. aphidis were dead (Fig. 2). At 28 days after inoculation, disease severity among sick plants that had been treated with $P$. aphidis was significantly lower (by $34.6 \%$ ) than that observed among the water-treated (control) plants (Table 2), and inoculated $P$. aphidis-treated plants were $25.3 \%$ taller than the inoculated control plants (Table 2). In addition, at that time point, there was a difference between the distribution of disease severity in the two treatments. Although all of the untreated plants showed symptoms of disease, $22 \%$ of the plants that had been treated with P. aphidis were completely free of disease symptoms (Fig. 3). Among the untreated plants, $27 \%$ exhibited disease symptoms (but remained alive) and $73 \%$ were dead. In comparison, $47 \%$ of the $P$. aphidis-treated plants exhibited disease symptoms (but remained alive) and only $31 \%$ were dead (Fig. 3).

$\boldsymbol{P}$. aphidis induces resistance in tomato plants. Three days after the application of live $P$. aphidis culture, expression of the PR genes $P R 1 a$ and PR5, chitinases 9 and 3 (Chit9 and Chit3, respectively), glucanases A and B (GlucA and $G l u c B$, respectively), and PTOinteracting protein 5 (PTI5) were upregulated relative to their expression levels in the untreated wild-type plants. However, no significant activation of the PR genes lipoxygenase $\mathrm{D}(L O X)$ and proteinase inhibitor II (PIN2) was observed in either treatment (Fig. 4A; Supplementary Fig. S1A). PRla was upregulated 30-fold relative to its expression in the water-treated wild-type plants and it

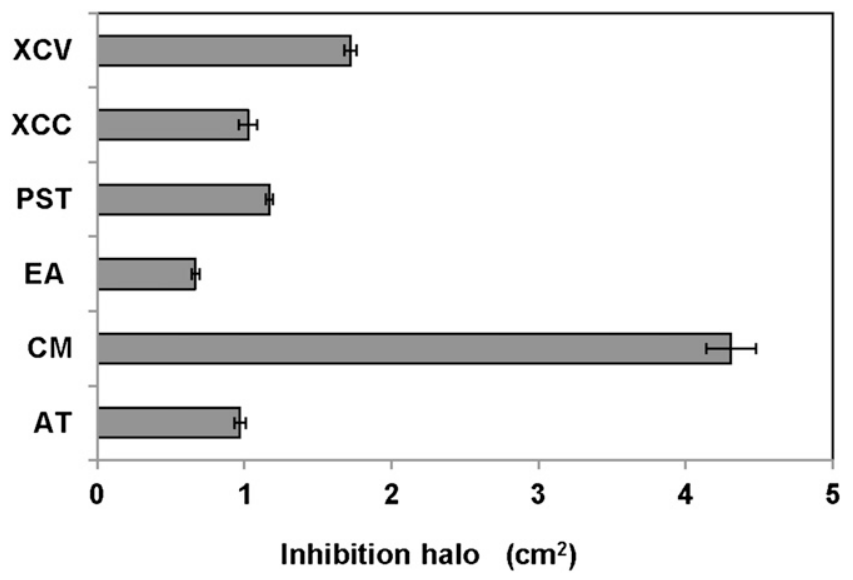

Fig. 1. In vitro inhibition of phytopathogens by Pseudozyma aphidis secretions. Crude hexane extract of $P$. aphidis secretions $(2 \mathrm{mg})$ was used for each bacterial inhibition assay. Whatman paper discs (6 $\mathrm{mm}$ in diameter) saturated with crude extract was placed on a potato dextrose agar plate containing the pathogen and inhibition halos were measured $48 \mathrm{~h}$ later. $\mathrm{XCV}=$ Xanthomonas campestris pv. vesicatoria, $\mathrm{XCC}=$ $X$. campestris pv. campestris, PST $=$ Pseudomonas syringe pv. tomato, $\mathrm{EA}=$ Erwinia amylovora, $\mathrm{CM}=$ Clavibacter michiganensis, and AT = Agrobacterium tumefaciens. Results represent means \pm standard error $(n=6)$. Shown here are the results of one experiment that was representative of at least four experiments with similar results. was the gene most upregulated by $P$. aphidis; therefore, we used it as our marker gene in subsequent experiments. In plants that had been inoculated with $C$. michiganensis, PRla expression was upregulated 10- to 11-fold before symptoms appeared, as compared with the uninfected, water-treated control plants. However, in plants that were treated with $P$. aphidis before being inoculated with C. michiganensis, PRIa was synergistically upregulated (29- to 30fold) as compared with the control plants (Fig. 4B). Other PR genes were also upregulated after inoculation with $C$. michiganensis but no further activation was seen when plants were pretreated with $P$. aphidis. PRla was not activated when we applied dead autoclaved $P$. aphidis on plants (Fig. 4B).

$P$. aphidis inhibits $C$. michiganensis on tomato plants in an SA-independent manner. When transgenic tomato plants with impaired SA accumulation (the salicylate hydroxylase-expressing transgenic plant $[N a h G])(29,47)$ were treated with $P$. aphidis and then inoculated with $C$. michiganensis, disease severity was similar to that observed among the wild-type plants (Table 3). This finding demonstrates that $P$. aphidis inhibits $C$. michiganensis in an SAindependent manner. We also found that, in $N a h G$ plants, the expression of $G l u c B$ was significantly upregulated 3 days after treatment with $P$. aphidis, while PRla and other PR genes demonstrated no activation or minor upregulation (Supplementary Fig. S2).

\section{Discussion}

We recently isolated a unique, biologically active isolate of $P$. aphidis from strawberry leaves and demonstrated that this isolate can reduce $B$. cinerea infection of tomato and Arabidopsis plants $(12,13)$. We further demonstrated that this biocontrol effect involves a dual mode of action (antibiosis and induced resistance) that is SA/ NPR1 and ET/JA independent $(12,13)$.

In the current work, we examined this isolate's ability to control bacterial plant pathogens. The $P$. aphidis isolate secreted metabolites that have inhibitory effects on several phytopathogenic bacteria in vitro. The secreted metabolites have not yet been identified but we demonstrated that crude extracts of these metabolites can inhibit several different bacterial pathogens in vitro (Fig. 1), including $C$. michiganensis, E. amylovora, Pseudomonas syringae pv. tomato, and $X$. campestris pv. vesicatoria. Antibiotic secretion is well established as a common mode of action of biocontrol agents $(6,32,43,56)$. We demonstrated that $P$. aphidis has an inhibitory effect on C. michiganensis in planta (Fig. 2; Table 2), in contrast to Avis

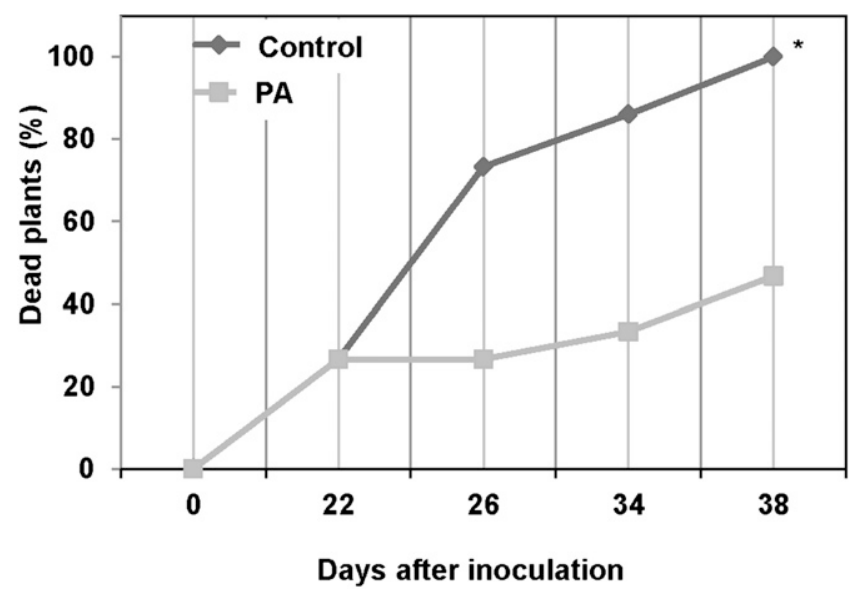

Fig. 2. In vivo inhibition of Clavibacter michiganensis by Pseudozyma aphidis. Whole 2-week-old greenhouse-grown tomato plants were sprayed with $P$. aphidis spores $\left(10^{8}\right.$ spores/ml; PA) or water (control) 3 days before being inoculated with C. michiganensis (optical density at $600 \mathrm{~nm}$ of approximately 0.9). Disease symptoms were monitored for 38 days following the inoculation and dead plants were scored. Asterisk denotes significant differences as determined using a Student's $t$ test, $P<0.05$. Results represent percentage of dead plants per treatment $(n=15)$. Shown here are the results of one experiment that was representative of at least four experiments with similar results. 
et al. (5), who demonstrated that $P$. aphidis provides no biocontrol; the difference between their findings and ours is most likely due to the use of different isolates (5). We demonstrated that application of $P$. aphidis before pathogen inoculation significantly reduces (by $60 \%$ ) the incidence of bacterial wilt and canker infection of tomato plants caused by $C$. michiganensis in the greenhouse (Fig. 2); moreover, disease severity was also reduced, by $34.6 \%$. Furthermore, $P$. aphidis-treated plants that were infected with $C$. michiganensis were $25.3 \%$ taller than infected, water-treated plants (Table 2). This might be explained by the fact that the $P$. aphidis -treated plants are healthier but also suggests as-yet-uncharacterized production or modulation of plant hormones, as demonstrated previously in plants treated with other beneficial microbes (30).

C. michiganensis subsp. michiganensis is the causal agent of the wilt and canker disease that is the most destructive bacterial disease in tomato plants worldwide (18). These bacteria enter into the host plant via wounds and natural openings and colonize the plant's vascular tissue. Systemic colonization of xylem vessels leads to leaf wilting, leaflet necrosis, and the spread of cankers on the plant stems, a process that eventually concludes in plant death (38). C. michiganensis infection activates the tomato plant's ET-dependent basal defense responses (7).

Application of $P$. aphidis to tomato plants (cultivar 870) activates their SA- and ET-dependent resistance pathways, as demonstrated by the activation of the PRIa and PTI5 marker genes $(16,64)$ (Fig. 4). However, it does not affect the expression of the LOX gene, which is a marker gene for the JA-dependent defense pathway (Fig. 4). In previous work, we demonstrated that $P$. aphidis also can activate the SA-dependent marker gene PR1 in Arabidopsis plants. In contrast to the effect observed in tomato plants, in Arabidopsis plants, the JA-dependent marker gene PDF1.2 was also activated (12). It has been previously shown that beneficial microorganisms can either

Table 2. Effect of Pseudozyma aphidis treatment on severity of disease symptoms caused by Clavibacter michiganensis ${ }^{z}$

\begin{tabular}{lcc}
\hline Treatments & DSI $(\%)$ & Stem length $(\mathbf{c m})$ \\
\hline Uninoculated control & 0 & $36.9 \pm 3.5 \mathrm{a}$ \\
Inoculated, $P$. aphidis treated & $50.3^{*}$ & $28.7 \pm 7.9 \mathrm{~b}$ \\
Inoculated, control, water treated & 76.9 & $22.9 \pm 4.2 \mathrm{c}$ \\
\hline
\end{tabular}

${ }^{\mathrm{z}}$ Disease severity index (DSI) was calculated 28 days postinoculation, as described by Raupach et al. (57). Means and standard deviations of stem length followed by different letters are significantly different according to the TukeyKramer honestly significant difference test; $P<0.05$. Means of DSI followed by an asterisk is significantly different from the control water-treated inoculated plants according to Student's $t$ test; $P<0.05 . n=10$.

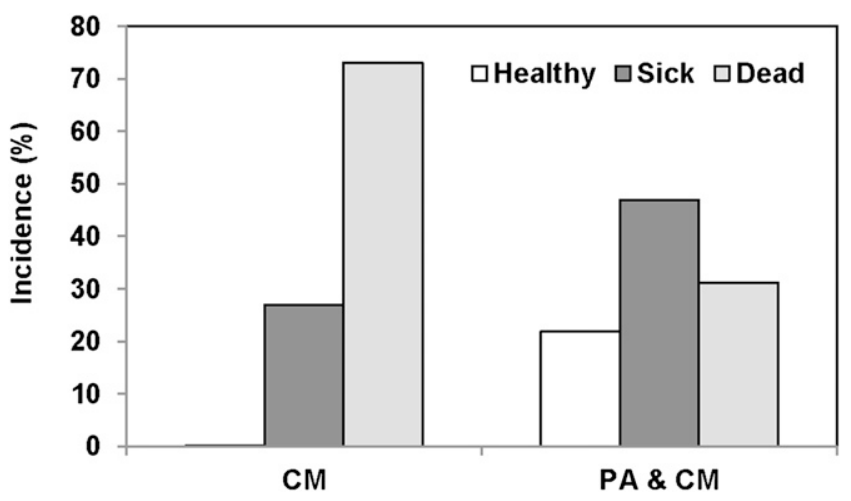

Fig. 3. Effect of Pseudozyma aphidis (PA) on the severity of disease induced by Clavibacter michiganensis (CM). The frequency of healthy, sick, and dead plants among the groups of plants inoculated with the pathogen with or without the PA treatment ( $n=15$ for each treatment) was calculated 28 days post inoculation. Shown here are the results of one experiment that was representative of at least four experiments with similar results. activate PR genes directly before pathogen attack $(14,71)$, as we demonstrated with $P$. aphidis, or can prime the plant without gene activation, resulting in rapid and strong PR gene activation upon pathogen attack $(17,67,70)$. The efficacy of $P$. aphidis for control of $C$. michiganensis in tomato plants (cultivar 870) correlated with the synergistic activation of the PRla gene in $P$. aphidis-treated plants that were inoculated with $C$. michiganensis (Fig. 4). These findings are in agreement with the current understanding that biotrophic bacterial resistance involves the activation of genes from

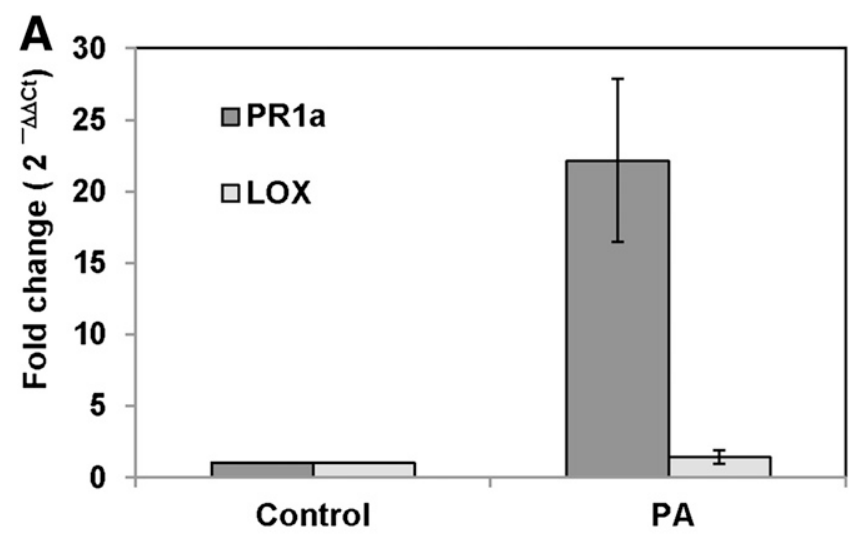

B

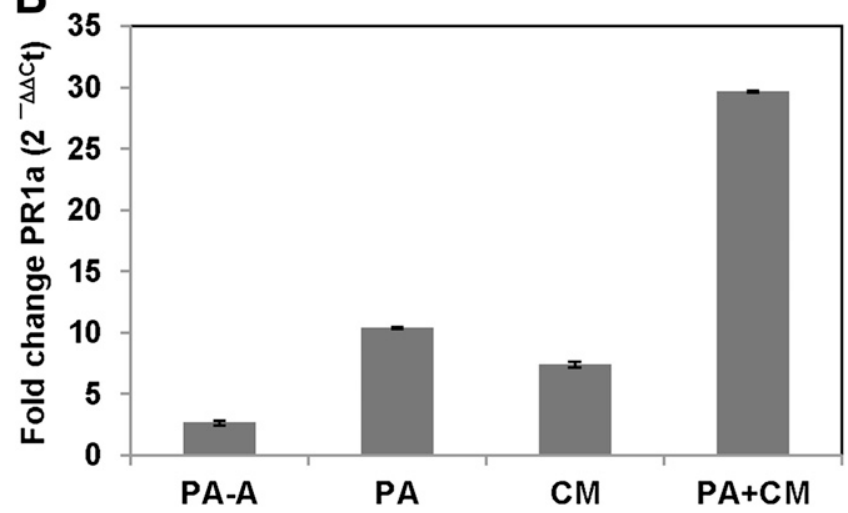

Fig. 4. Resistance induced by Pseudozyma aphidis (PA). Wild-type tomato plants were sprayed with a suspension of PA spores $\left(10^{8}\right.$ spores $\left./ \mathrm{ml}\right)$. LoxD (LOX) and $P R 1 a$ gene expression was monitored using quantitative real-time polymerase chain reaction. A, Relative gene expression at 3 days after the application of PA, relative to that observed in water-treated plants (control). B, Relative gene expression at 28 days after Clavibacter michiganensis (CM) was applied to plants treated with live $P$. aphidis (PA) or dead autoclaved $P$. aphidis (PA-A) as compared with water-treated plants (control). Relative gene expression ( $R Q$ ) was calculated using the $2^{-\Delta \Delta \mathrm{CT}}$ method. Results represent means \pm standard error $(n=3)$. Shown here are the results of one experiment that was representative of at least four experiments with similar results.

Table 3. Effect of Pseudozyma aphidis treatment on severity of disease symptoms induced by Clavibacter michiganensis in wild-type (WT) and NahG mutant plants $^{\mathrm{z}}$

\begin{tabular}{|c|c|c|c|c|}
\hline \multirow[b]{2}{*}{ Treatment } & \multicolumn{2}{|c|}{ DSI (\%) } & \multicolumn{2}{|c|}{$\begin{array}{c}\text { Stem length } \\
(\mathrm{cm} ; \text { mean } \pm \text { SD) }\end{array}$} \\
\hline & WT & $N a h G$ & WT & $N a h G$ \\
\hline Inocu & 35.5 & 35 & $56.6 \pm 2.5$ & $57.6 \pm 5.8$ \\
\hline Inoculated, control water-treated & $47 *$ & 51 & $45.2 \pm 4.6$ & $48.1 \pm 6.2$ \\
\hline
\end{tabular}

$\mathrm{z}$ Disease severity index (DSI) was calculated 42 days postinoculation, as described by Raupach et al. (57). Means and standard deviations (SD) of stem length followed by different letters are significantly different according to the Tukey-Kramer honestly significant difference test, $P<0.05$. Means of DSI followed by asterisk is significantly different from control according to Student's $t$ test, $P<0.05 . n=10$. 
the SA-dependent pathway (45). However, we cannot rule out the possibility of the involvement of other, as-yet-unidentified SAindependent PR genes and other hormonal pathways activation after $P$. aphidis application. Indeed, when we treated $N a h G$-transgenic tomato plants (Money Maker background), which do not accumulate SA and do not activate PR1a, with $P$. aphidis, we observed a reduction in the severity of disease induced by $C$. michiganensis (Table 3 ). This indicates that the inhibition of $C$. michiganensis by $P$. aphidis is SA-independent in Money Maker background and probably involves genes other than PR1a, such as GlucB, PTI5, and PR5 that were upregulated in this cultivar. Furthermore, PR1a upregulation could not be demonstrated after $P$. aphidis application in NahG plants, as expected, but it was also lower in their corresponding wild-type background Money Maker as compared with cultivar 870. This is consistent with a previous observation that demonstrated that different tomato cultivars respond differently to the biocontrol agent Trichoderma and activate different sets of PR genes (65). It is also a possibility that other PR genes and hormonal pathways, as-yetunidentified, are also involved in the defense response against $C$. michiganensis after $P$. aphidis application in both cultivars. Using $N a h G$-transgenic Arabidopsis plants infected with $B$. cinerea, we previously suggested that $P$. aphidis either bypasses the SA pathway to activate downstream PR genes or activates other as-yetundiscovered defense pathways (12). Alternatively, the systemic resistance in an SA-independent manner can also be activated without activation of PR gene expression as also suggested by other works using the biocontrol agent Pseudomonas fluorescens $(8,52-54,58,61)$ and for rhizobacterial species $(8,69,73)$. Involvement of an SAindependent pathway in induced-resistance activation has been shown before using the biocontrol agent $T$. harzianum $(41,50)$. On the other hand, some beneficial microorganisms activate SA-dependent induced resistance $(1,19)$, but different pathways might also be involved $(36,37,68)$. Recent work demonstrated that $C$. michiganensis activated the ET defense pathway in tomato plants (7). We also demonstrated activation of the ET-dependent PTI5 after $P$. aphidis treatment in both cultivars but it was not upregulated in cultivar 870 after infection with C. michiganensis. Furthermore, PTI5 was not upregulated also in NahG plants as was expected according to the previous results, suggesting that SA suppresses PTI5 activation (31). Differences in plant genotypes used in the various studies might be responsible for the alterations in defense responses. As $C$. michiganensis is mainly a systemic pathogen, it is likely that much of the biocontrol effect we observed using the epiphytic $P$. aphidis resulted from activation of induced resistance. Nevertheless, we cannot rule out the possibility of a direct antibiosis effect achieved during pathogen inoculation and dispersal via wounds and natural openings. In summary, in this article, we demonstrate the ability of $P$. aphidis to reduce the incidence of infection of tomato plants by $C$. michiganensis and to activate the plant's defense system in an SA-independent manner.

\section{Literature Cited}

1. Ahn, I. P., Park, K., and Kim, C. H. 2002. Rhizobacteria-induced resistance perturbs viral disease progress and triggers defense-related gene expression. Mol. Cells 13:302-308.

2. Alfano, G., Ivey, M. L. L., Cakir, C., Bos, J. I. B., Miller, S. A., Madden, L. V., Kamoun, S., and Hoitink, H. A. J. 2007. Systemic modulation of gene expression in tomato by Trichoderma hamatum 382. Phytopathology 97: 429-437.

3. Avis, T. J., and Belanger, R. R. 2001. Specificity and mode of action of the antifungal fatty acid cis-9-heptadecenoic acid produced by Pseudozyma flocculosa. Appl. Environ. Microbiol. 67:956-960.

4. Avis, T. J., and Belanger, R. R. 2002. Mechanisms and means of detection of biocontrol activity of Pseudozyma yeasts against plant-pathogenic fungi. FEMS Yeast Res. 2:5-8.

5. Avis, T. J., Caron, S. J., Boekhout, T., Hamelin, R. C., and Belanger, R. R. 2001. Molecular and physiological analysis of the powdery mildew antagonist Pseudozyma flocculosa and related fungi. Phytopathology 91:249-254.

6. Bailey, B., Bae, H., Strem, M., Crozier, J., Thomas, S., Samuels, G., Vinyard, B., and Holmes, K. 2008. Antibiosis, mycoparasitism, and colonization success for endophytic Trichoderma isolates with biological control potential in Theobroma cacao. Biol. Control 46:24-35.

7. Balaji, V., Mayrose, M., Sherf, O., Jacob-Hirsch, J., Eichenlaub, R., Iraki, N., Manulis-Sasson, S., Rechavi, G., Barash, I., and Sessa, G. 2008. Tomato transcriptional changes in response to Clavibacter michiganensis subsp. michiganensis reveal a role for ethylene in disease development. Plant Physiol. 146:1797-1809.

8. Bargabus-Larson, R. L., and Jacobsen, B. J. 2007. Biocontrol elicited systemic resistance in sugarbeet is salicylic acid independent and NPR1 dependent J. Sugar Beet Res. 44:17-33.

9. Bélanger, R. R., Labbé, C., and Jarvis, W. R. 1994. Commercial-scale control of rose powdery mildew with a fungal antagonist. Plant Dis. 78:420-424.

10. Benyagoub, M., Willemot, C., and Bélanger, R. R. 1996. Influence of a subinhibitory dose of antifungal fatty acids from Sporothrix flocculosa on cellular lipid composition in fungi. Lipids 31:1077-1082.

11. Boekhout, T. 1995. Pseudozyma Bandoni emend. Boekhout, a genus for yeastlike anamorphs of Ustilaginales. Gen. Appl. Microbiol. 41:359-366.

12. Buxdorf, K., Rahat, I., Gafni, A., and Levy, M. 2013. The epiphytic fungus Pseudozyma aphidis induces jasmonic acid- and salicylic acid/nonexpressor of PR1-independent local and systemic resistance. Plant Physiol. 161 2014-2022.

13. Buxdorf, K., Rahat, I., and Levy, M. 2013. Pseudozyma aphidis induces ethylene-independent resistance in plants. Plant Signal. Behav. 8:11, e26273.

14. Cartieaux, F., Thibaud, M. C., Zimmerli, L., Lessard, P., Sarrobert, C., David, P., Gerbaud, A., Robaglia, C., Somerville, S., and Nussaume, L. 2003 Transcriptome analysis of Arabidopsis colonized by a plant-growth promoting rhizobacterium reveals a general effect on disease resistance. Plant J. 36:177-188.

15. Chand-Goyal, T., and Spotts, R. A. 1996. Enumeration of bacterial and yeast colonists of apple fruits and identification of epiphytic yeasts on pear fruits in the Pacific Northwest United States. Microbiol. Res. 151:427-432.

16. Chao, W. S., Gu, Y. Q., Pautot, V. V., Bray, E. A., and Walling, L. L. 1999 Leucine aminopeptidase RNAs, proteins, and activities increase in response to water deficit, salinity, and the wound signals systemin, methyl jasmonate, and abscisic acid. Plant Physiol. 120:979-992.

17. Conrath, U., Beckers, G. J. M., Flors, V., García-Agustín, P., Jakab, G., Mauch, F., Newman, M. A., Pieterse, C. M. J., Poinssot, B., Pozo, M. J., Pugin, A., Schaffrath, U., Ton, J., Wendehenne, D., Zimmerli, L., and Mauch-Mani, B. 2006. Priming: Getting ready for battle. Mol. PlantMicrobe Interact. 19:1062-1071.

18. Davis, M. J., Gillaspie, A. G., Vidaver, A. K., and Harris, R. W. 1984 Clavibacter: A new genus containing some phytopathogenic coryneform bacteria, Including Clavibacter xyli subsp. xyli sp. nov., subsp. nov. and Clavibacter xyli subsp. cynodontis subsp. nov., pathogens that cause ratoon stunting disease of sugarcane and bermudagrass stunting disease. Int. J. Syst. Bacteriol. 34:107-117.

19. De Meyer, G., Audenaert, K., and Höfte, M. 1999. Pseudomonas aeruginosa 7NSK2-induced systemic resistance in tobacco depends on in planta salicylic acid accumulation but is not associated with PR1a expression. Eur. J. Plant Pathol. 105:513-517.

20. Dik, A. J., and Elad, Y. 1999. Comparison of antagonists of Botrytis cinerea in greenhouse-grown cucumber and tomato under different climatic conditions. Eur. J. Plant Pathol. 105:123-137.

21. Dik, A. J., Koning, G., and Köhl, J. 1999. Evaluation of microbial antagonists for biological control of Botrytis cinerea stem infection in cucumber and tomato. Eur. J. Plant Pathol. 105:115-122.

22. Dik, A. J., Verhaar, M. A., and Bélanger, R. R. 1998. Comparison of three biological control agents against cucumber powdery mildew (Sphaerotheca fuliginea) in semi-commercial-scale glasshouse trials. Eur. J. Plant Pathol. 104:413-423.

23. Droby, S., Vinokur, V., Weiss, B., Cohen, L., Daus, A., Goldschmidt, E. E., and Porat, R. 2002. Induction of resistance to Penicillium digitatum in grapefruit by the yeast biocontrol agent Candida oleophila. Phytopathology 92:393-399.

24. Droby, S., Wisniewski, M., El Ghaouth, A., and Wilson, C. 2003. Influence of food additives on the control of postharvest rots of apple and peach and efficacy of the yeast-based biocontrol product aspire. Postharvest Biol. Technol. 27:127-135.

25. Exposito-Rodriguez, M., Borges, A., Borges-Perez, A., Hernandez, M., and Perez, J. 2007. Cloning and biochemical characterization of ToFZY, a tomato gene encoding a flavin monooxygenase involved in a tryptophandependent auxin biosynthesis pathway. J. Plant Growth Regul. 26:329-340.

26. Filonow, A. B., Vishniac, H. S., Anderson, J. A., and Janisiewicz, W. J. 1996 Biological control of Botrytis cinerea in apple by yeasts from various habitats and their putative mechanisms of antagonism. Biol. Control 7:212-220.

27. Fokkema, N. J., and Schippers, B. 1986. Phyllosphere Versus Rhizosphere as Environments for Saprophytic Colonization. Cambridge University Press, Cambridge.

28. Fokkema, N. J., van de Laar, J. A. J., Nellis-Blomberg, A. L., and Schippers, B. 1975. The buffering capacity of the natural mycoflora of rye leaves to infection by Cochliobolus sativus and its susceptibility to benomyl. Neth. J. Plant Pathol. 81:176-186.

29. Gaffney, T., Friedrich, L., Vernooij, B., Negrotto, D., Nye, G., Uknes, S., Ward, E., Kessmann, H., and Ryals, J. 1993. Requirement of salicylic acid for the induction of systemic acquired resistance. Science 261:754-756.

30. Glick, B. R. 2012. Plant growth-promoting bacteria: Mechanisms and applications. Scientifica 2012:Article ID 96340. 
31. Gu, Y.-Q., Wildermuth, M. C., Chakravarthy, S., Loh, Y.-T., Yang, C., He, X., Han, Y., and Martin, G. B. 2002. Tomato transcription factors Pti4, Pti5, and Pti6 activate defense responses when expressed in Arabidopsis. The Plant Cell Online 14:817-831

32. Haas, D., and Keel, C. 2003. Regulation of antibiotic production in rootcolonizing Pseudomonas spp. and relevance for biological control of plant disease. Annu. Rev. Phytopathol. 41:117-153.

33. Hajlaou, M. R., Traquair, J. A., Jarvis, W. R., and Bélanger, R. R. 1994. Antifungal activity of extracellular metabolites produced by Sporothrix flocculosa. Biocontrol Sci. Technol. 4:229-237.

34. Hajlaoui, M. R., and Bélanger, R. R. 1991. Comparative effects of temperature and humidity on the activity of three potential antagonists of rose powdery mildew. Neth. J. Plant Pathol. 97:203-208

35. Hajlaoui, M. R., and Bélanger, R. R. 1993. Antagonism of the yeast-like phylloplane fungus Sporothrix flocculosa against Erysiphe graminis var. tritici. Biocontrol Sci. Technol. 3:427-434.

36. Harman, G. E. 2006. Overview of mechanisms and uses of Trichoderma spp. Phytopathology 96:190-194.

37. Hossain, M. M., Sultana, F., Kubota, M., Koyama, H., and Hyakumachi, M. 2007. The plant growth-promoting fungus Penicillium simplicissimum GP17-2 induces resistance in Arabidopsis thaliana by activation of multiple defense signals. Plant Cell Physiol. 48:1724-1736.

38. Jahr, H., Bahro, R., Burger, A., Ahlemeyer, J., and Eichenlaub, R. 1999. Interactions between Clavibacter michiganensis and its host plants. Environ. Microbiol. 1:113-118.

39. Jarvis, W. R., Shaw, L. A., and Traquair, J. A. 1989. Factors affecting antagonism of cucumber powdery mildew by Stephanoascus flocculosus and S. rugulosus. Mycol. Res. 92:162-165.

40. Karabulut, O. A., Arslan, U., and Kuruoglu, G. 2004. Control of postharvest diseases of organically grown strawberry with preharvest applications of some food additives and postharvest hot water dips. J. Phytopathol. 152:224-228.

41. Korolev, N., David, D. R., and Elad, Y. 2008. The role of phytohormones in basal resistance and Trichoderma-induced systemic resistance to Botrytis cinerea in Arabidopsis thaliana. BioControl 53:667-683.

42. Last, F. T., and Price, D. 1969. Yeasts Associated with Living Plants and Their Environs, 1st ed. Academic Press, New York and London.

43. Lin, Y., Du, D., Si, C., Zhao, Q., Li, Z., and Li, P. 2014. Potential biocontrol Bacillus sp. strains isolated by an improved method from vinegar waste compost exhibit antibiosis against fungal pathogens and promote growth of cucumbers. Biol. Control 71:7-15.

44. Livak, K. J., and Schmittgen, T. D. 2001. Analysis of relative gene expression data using real-time quantitative PCR and the $2^{-\Delta \Delta C T}$. Methods 25:402-408.

45. McDowell, J. M., and Dangl, J. L. 2000. Signal transduction in the plant immune response. Trends Biochem. Sci. 25:79-82

46. McLaughlin, R. J., Wilson, C. L., Droby, S., Ben-Arie, R., and Chalutz, E. 1992. Biological control of postharvest diseases of grape, peach, and apple with the yeasts Kloeckera apiculata and Candida guilliermondii. Plant Dis. 76:470-473.

47. Oldroyd, G. E., and Staskawicz, B. J. 1998. Genetically engineered broadspectrum disease resistance in tomato. Proc. Natl. Acad. Sci. USA 95: 10300-10305.

48. Paulitz, T. C., and Belanger, R. R. 2001. Biological control in greenhouse systems. Annu. Rev. Phytopathol. 39:103-133.

49. Paz, Z., Burdman, S., Gerson, U., and Sztejnberg, A. 2007. Antagonistic effects of the endophytic fungus Meira geulakonigii on the citrus rust mite Phyllocoptruta oleivora. J. Appl. Microbiol. 103:2570-2579.

50. Perazzolli, M., Dagostin, S., Ferrari, A., Elad, Y., and Pertot, I. 2008. Induction of systemic resistance against Plasmopara viticola in grapevine by Trichoderma harzianum T39 and benzothiadiazole. Biol. Control 47:228-234.

51. Phaff, H. J., and Starmer, W. T. 1987. Yeasts Associated with Plants, Insects and Soil, 2nd ed. Academic Press, London.

52. Pieterse, C. M., van Wees, S. C., Hoffland, E., van Pelt, J. A., and van Loon, L. C. 1996. Systemic resistance in Arabidopsis induced by biocontrol bacteria is independent of salicylic acid accumulation and pathogenesis-related gene expression. Plant Cell 8:1225-1237.

53. Pieterse, C. M. J., Van Pelt, J. A., Van Wees, S. C. M., Ton, J., LéonKloosterziel, K. M., Keurentjes, J. J. B., Verhagen, B. W. M., Knoester, M.,
Van der Sluis, I., Bakker, P. A. H. M., and Van Loon, L. C. 2001. Rhizobacteria-mediated induced systemic resistance: Triggering, signalling and expression. Eur. J. Plant Pathol. 107:51-61.

54. Pieterse, C. M. J., van Wees, S. C. M., Ton, J., van Pelt, J. A., and van Loon, L. C. 2002. Signalling in rhizobacteria-induced systemic resistance in Arabidopsis thaliana. Plant Biol. 4:535-544.

55. Punja, Z. K., and Utkhede, R. S. 2003. Using fungi and yeasts to manage vegetable crop diseases. Trends Biotechnol. 21:400-407.

56. Raaijmakers, J. M., Vlami, M., and De Souza, J. T. 2002. Antibiotic production by bacterial biocontrol agents. Antonie Leeuwenhoek 81:537-547.

57. Raupach, G. S., Liu, L., Murphy, J. F., Tuzun, S., and Kloepper, J. W. 1996 Induced systemic resistance in cucumber and tomato against cucumber mosaic cucumovirus using plant growth-promoting rhizobacteria (PGPR). Plant Dis 80:891-894.

58. Ryu, C. M., Hu, C. H., Reddy, M., and Kloepper, J. W. 2003. Different signaling pathways of induced resistance by rhizobacteria in Arabidopsis thaliana against two pathovars of Pseudomonas syringae. New Phytol. 160:413-420.

59. Shoresh, M., Harman, G. E., and Mastouri, F. 2010. Induced systemic resistance and plant responses to fungal biocontrol agents. Annu. Rev. Phytopathol. 48:21-43.

60. Shoresh, M., Yedidia, I., and Chet, I. 2005. Involvement of jasmonic acid/ ethylene signaling pathway in the systemic resistance induced in cucumber by Trichoderma asperellum T203. Phytopathology 95:76-84.

61. Siddiqui, I., and Shaukat, S. 2004. Systemic resistance in tomato induced by biocontrol bacteria against the root-knot nematode, Meloidogyne javanica is independent of salicylic acid production. J. Phytopathol. 152:48-54.

62. Starmer, W. T., Ganter, P. F., Aberdeen, V., Lachance, M. A., and Phaff, H. J. 1987. The ecological role of killer yeasts in natural communities of yeasts. Can. J. Microbiol. 33:783-796.

63. Stein, E., Molitor, A., Kogel, K. H., and Waller, F. 2008. Systemic resistance in Arabidopsis conferred by the mycorrhizal fungus Piriformospora indica requires jasmonic acid signaling and the cytoplasmic function of NPR1. Plant Cell Physiol. 49:1747-1751.

64. Tornero, P., Gadea, J., Conejero, V., and Vera, P. 1997. Two PR-1 genes from tomato are differentially regulated and reveal a novel mode of expression for a pathogenesis-related gene during the hypersensitive response and development. Mol. Plant Microbe Interact. 10:624-634

65. Tucci, M., Ruocco, M., De Masi, L., De Palma, M., and Lorito, M. 2011. The beneficial effect of Trichoderma spp. on tomato is modulated by the plant genotype. Mol. Plant Pathol. 12:341-354.

66. Urquhart, E. J., and Punja, Z. K. 2002. Hydrolytic enzymes and antifungal compounds produced by Tilletiopsis species, phyllosphere yeasts that are antagonists of powdery mildew fungi. Can. J. Microbiol. 48:219-229.

67. van Hulten, M., Pelser, M., Van Loon, L., Pieterse, C. M., and Ton, J. 2006 Costs and benefits of priming for defense in Arabidopsis. Proc. Natl. Acad. Sci. USA 103:5602-5607.

68. van Loon, L. C. 2007. Plant responses to plant growth-promoting rhizobacteria. Eur. J. Plant Pathol. 119:243-254.

69. Van Wees, S. C., Pieterse, C. M., Trijssenaar, A., Van 't Westende, Y. A., Hartog, F., and Van Loon, L. C. 1997. Differential induction of systemic resistance in Arabidopsis by biocontrol bacteria. Mol. Plant-Microbe Interact. 10:716-724.

70. Verhagen, B. W., Glazebrook, J., Zhu, T., Chang, H. S., van Loon, L. C., and Pieterse, C. M. 2004. The transcriptome of rhizobacteria-induced systemic resistance in Arabidopsis. Mol. Plant-Microbe Interact. 17:895-908.

71. Wang, Y., Ohara, Y., Nakayashiki, H., Tosa, Y., and Mayama, S. 2005 Microarray analysis of the gene expression profile induced by the endophytic plant growth-promoting rhizobacteria, Pseudomonas fluorescens FPT9601-T5 in Arabidopsis. Mol. Plant-Microbe Interact. 18:385-396.

72. Yaffe, H., Buxdorf, K., Shapira, I., Ein-Gedi, S., Moyal-Ben Zvi, M., Fridman, E., Moshelion, M., and Levy, M. 2012. LogSpin: A simple, economical and fast method for RNA isolation from infected or healthy plants and other eukaryotic tissues. BMC Res. Notes 5:45.

73. Yan, Z., Reddy, M., Ryu, C.-M., McInroy, J. A., Wilson, M., and Kloepper, J. W. 2002. Induced systemic protection against tomato late blight elicited by plant growth-promoting rhizobacteria. Phytopathology 92:1329-1333. 